\title{
Recent Advances in Research of HIV Infection: Implications of Viral and Host Genetics on Treatment and Prevention
}

\author{
R.E. Haaland ${ }^{\text {a }} \quad$ J.A. Johnson ${ }^{\text {a }} \quad$ J. Tang ${ }^{\text {b }}$ \\ a Laboratory Branch, Division of HIV/AIDS Prevention, National Center for HIV/AIDS, Viral Hepatitis, STD and TB \\ Prevention, Centers for Disease Control and Prevention, Atlanta, Ga., and ${ }^{b}$ Department of Medicine, University of \\ Alabama at Birmingham, Birmingham, Ala., USA
}

\section{Key Words}

AIDS - Antiretroviral drug resistance $\cdot$ Human

immunodeficiency virus · Immunogenetics · Transmission

\begin{abstract}
The genetic diversity among human immunodeficiency virus (HIV) subtypes as well as the variability of viral sequences found in HIV-infected individuals presents a number of difficult obstacles for the development of universally effective HIV treatment and prevention methods. Here, we present a brief summary of recent developments in the analysis of viral genetics and human genomics to provide insight into future methods for HIV treatment and prevention. Recent studies have mined viral sequences found in newly infected individuals to identify common features of all transmitted viruses that could provide potential targets for HIV vaccine development. Analysis of human immunogenetics has identified specific alleles associated with reduced virus loads in HIVinfected individuals providing valuable information that may influence individual responses to treatment and prevention methods. Increased sensitivity of antiretroviral drug resistance testing has improved the detection of hidden drug resistant virus but also highlighted the potential for drug resistant viruses to reduce the effectiveness of clinical treatment regimens. The rapidly expanding amount of data
\end{abstract}

\begin{tabular}{ll}
\hline KARGER & $\begin{array}{l}\text { (c) 2013 S. Karger AG, Basel } \\
1662-4246 / 13 / 0162-0031 \$ 38.00 / 0\end{array}$ \\
E-Mail karger@karger.com & $\begin{array}{l}\text { This is an Open Access article licensed under the terms of } \\
\text { the Creative Commons Attribution-NonCommercial-No- } \\
\text { www.karger.com/phg }\end{array}$ \\
$\begin{array}{l}\text { Derivs 3.0 License (www.karger.com/OA-license), applica- } \\
\text { ble to the online version of the article only. Distribution for } \\
\text { non-commercial purposes only. }\end{array}$
\end{tabular}

generated by studies of viral genetics and human immunogenetics will provide valuable information to guide the design of new strategies to improve clinical treatment and enhance HIV vaccine development.

Copyright $\odot 2013$ S. Karger AG, Basel

\section{Introduction}

The pandemic of human immunodeficiency virus (HIV) infection continues to pose an enormously difficult public health challenge for a multitude of reasons. One of the most daunting aspects of the HIV epidemic is the extremely high level of genetic diversity among the 13 recognized global subtypes and at least 51 circulating recombinant forms [1]. The degree of global diversity observed originates with the error-prone nature of the viral replication machinery and the ability of the viral genome to incorporate multiple nucleotide substitutions which, within infected individuals, results in a population of closely related, but genetically distinct variants termed quasispecies. Evolving HIV genetic diversity presents numerous obstacles for both the human immune response as well as the implementation of antiviral therapies, vaccines and microbicides. Recent studies utilizing new sequencing technologies and genomics tools have begun to

Richard E. Haaland

Centers for Disease Control and Prevention

1600 Clifton Road, M/S A-25

Atlanta, GA 30333 (USA)

E-Mail hyw9@cdc.gov 
reveal a vast amount of data regarding the genetics of both HIV and the human immune system. In this review, we will present a brief summary of recent studies examining HIV genetics and human genomics as well as how this body of knowledge will impact the development and implementation of future effective methods to both treat and prevent HIV infection.

\section{Genetic Analysis of Transmitted Variants}

Although the HIV global epidemic is characterized by an extraordinarily high level of viral genetic diversity, the viral quasispecies initially found in most individuals early in infection tends to be remarkably homogenous. Recent studies have focused on sampling sequences of the viral env gene from the viral quasispecies within HIVinfected individuals. The viral env gene encodes the highly variable viral surface glycoprotein (Env) required for entry into HIV target cells. Several studies based on recently infected individuals have established that in 60 $90 \%$ of cases, depending on the population studied, HIV infection is apparently established by a single viral variant [2]. In multiple variant infections, only $2-5$ variants can be found, although higher infection multiplicities have not been ruled out because sampling for many tissue compartments is not readily available. Infection with multiple variants has been observed to occur more frequently when the barrier of the host mucosal surface is compromised or bypassed, as with sexually transmitted infections, anal intercourse or intravenous drug users [3]. Additionally, infection with multiple variants has been linked to certain markers of faster disease progression [4]. Therefore, methods aimed at reducing the likelihood of infection with multiple variants, such as treatment of sexually transmitted infections in HIV-uninfected persons, will likely slow disease progression in those individuals who become HIV-infected.

Advances in bioinformatics analysis have enabled the compilation and comparison of viral sequences collected from a large number of newly infected individuals to identify common sequences and phenotypes that may be shared in HIV transmission. A recent study by Gnanakaran et al. [5] examined over 7,000 env sequences obtained from 275 samples collected during acute or chronic phases of HIV infection to search for signature genetic patterns specifically associated with acute infection. This analysis yielded 25 promising signatures, including the absence of a specific sequence known to facilitate viral escape from antibodies and several signatures that may be essential to proper expression and/or processing of the Env glycoprotein. Asmal et al. [6] extended this finding by demonstrating that sequences associated with acute infection indeed produce higher levels of Env and increased incorporation of Env into virions in vitro. Together these studies highlight the potential utility of mining large data sets of viral sequences from acute and chronic HIV infection for genetic patterns uniquely related to HIV transmission before specific hypotheses are further tested in experimental systems. Thus, genetic analysis of viral sequences has begun to identify specific properties of all HIV transmitted variants that may be targeted in future vaccine and microbicide methods to prevent sexual transmission of HIV.

Evaluation of viral sequences in samples collected during clinical trials of HIV prevention strategies also afford the opportunity to examine breakthrough infections in treatment and control arms to identify characteristics of viral variants that manage to establish infection in the context of a specific intervention. The STEP trial, a double-blinded, phase $2 b$ study of vaccine efficacy, attempted to induce immune responses against 3 HIV proteins, but the trial lacked efficacy in preventing infection [7]. Retrospectively, Rolland et al. [8] obtained and compared near full-length viral genomes from $68 \mathrm{HIV}$-infected individuals from both the vaccine and placebo arms of the STEP trial. Not surprisingly, breakthrough infections in the vaccine recipients were initiated by viruses with sequences divergent from the vaccine. Importantly, sequence differences between viruses establishing infection in vaccine and placebo recipients were almost exclusively restricted to the 3 viral proteins that comprised the vaccine. Thus, while this analysis highlights the challenges facing HIV vaccine development, the application of viral genetic analysis to breakthrough infections in clinical trials is being used to hone previously tested prevention methods in order to maximize efficacy. Taken together, novel strategies of analyzing HIV sequences are beginning to yield promising opportunities to develop new, and improve upon current, HIV prevention methods.

\section{Insights from Analyses of Host Genomics}

HIV diversity and its continuing evolution in human populations are dictated in part by host factors, including those that mediate innate and adaptive immune responses to HIV infection [9]. Comprehensive data from deep sequencing of the entire HIV genome [10] coupled with genome-wide search for host genetic factors important to 
HIV acquisition and control [11] are expected to facilitate a fine dissection of molecular mechanisms underlying the battle between HIV and host genomes.

To date, immunogenetics as a prominent frontier in AIDS research has already made important contributions to (i) identification of HIV-resistance factors (e.g. null CCR5 alleles), (ii) the understanding of effective and durable immune control of HIV infection in elite or viremic controllers [12], (iii) mapping of viral epitopes for vaccine design, and (iv) evaluation of vaccine efficacy. Although human genomes have been scanned for patient populations with informative, HIV-related phenotypes [13, 14], several recent studies now offer new evidence that productive and transformative research may need to focus on systematic analysis of highly polymorphic human leukocyte antigen (HLA) molecules and killer cell immunoglobulin-like receptor (KIR) genes. Continued study of the complex virus/host interaction will inform development and implementation of treatment and prevention regimens.

For example, 2 recent studies have demonstrated that individuals infected with HIV subtypes B and C have relatively low viral load when they carry HLA-DRB1*13:03, an infrequent allele that might have been missed by earlier studies for lack of statistical power $[15,16]$. Favorable HLA class II alleles are likely to target epitopes in HIV Gag instead of Env [16], which is consistent with the wellestablished notion that immune recognition of conserved epitopes in HIV Gag may be a common mechanism for effective immune control, as immune escape mutations in Gag typically lead to reduced viral fitness. In the AIDS vaccine trial (RV144) in Thailand, lack of neutralizing antibody (nAb) response was associated with HLA-DRB1 variants ${ }^{*} 11$ and ${ }^{*} 16: 02$ [17]; vaccine recipients with the HLA-DQ heterodimer consisting of DQA $1 * 05: 01$ and DQB1*03:01 were also unlikely to produce $n A b$ after vaccination [17]. Future vaccine trials may need to consider HLA class II genotyping as another useful tool for deciphering correlates of immune protection, as supported by preclinical findings from an SIV-macaque model [18]. Of note, HLA class II alleles implicated by the RV144 trial bear no similarity to those (e.g. DRB1 ${ }^{*} 01,{ }^{*} 03,{ }^{*} 07$ and *15) reported earlier for several routinely applied vaccines, suggesting that $\mathrm{nAb}$ responses may differ by vaccine constructs and/or dosing regimens.

Unlike potent anti-HIV nAb that acts relatively late in the course of HIV infection, CTLs and NK cells presumably act early. As such, HLA class I and KIR gene variants with distinct functional properties can be analyzed against early phenotypes. This hypothesis has been tested in re-

Viral and Host Genetics in HIV Infection cent HIV seroconverters from sub-Saharan African countries [19]. In the acute-phase of HIV infection (duration of infection $<3$ months), the majority of seroconverters with effective control of viremia had HLA-B*44 and $B^{*}$ $57-2$ favorable HLA variants in the cohort [19]. These allelic products are known to target multiple conserved HIV epitopes, but their functional advantages may also further reflect intrinsic differences in protein expression [20]. One study has also called for close attention to HLAC expression, as certain alleles (e.g. $C^{*} 06: 02$ ) may be functionally advantageous through avoidance of down-regulation by microRNAs [21]. HLA-KIR interactions can provide another dimension for gauging the relevance of HLA function to HIV control, as at least 22 nonsynonymous mutations in the HIV genome are apparently attributable to several KIR genes (especially KIR2DL2) [22]. A clear picture about these multifactorial and multidimensional pathways may emerge soon to allow a finemapping of HIV mutations induced by CTL, nAb, NK, and other related effectors mediated by HLA and KIR gene products. However, it will require much more painstaking effort to determine the selection of these mutations relative to individual immune pressure, their patterns of reversion in the absence of immune pressure, and the replication capacity of mutated viruses. Further study will be necessary to understand the interplay between human immunogenetics and HIV in order to implement treatment and prevention methods with maximum efficacy.

\section{Detection of Antiretroviral Drug Resistance}

A complication in HIV clinical care stemming from the high mutation rate and genetic diversity of HIV is the emergence and persistence of mutations that confer resistance to drugs used in antiretroviral therapy (ART). Because primary or transmitted drug resistance mutations are associated with poorer treatment outcomes, a Department of Health and Human Services panel recommended that all persons newly diagnosed with HIV infection receive an HIV genotype prior to initiating therapy [23]. The conventional method for virus genotyping is Sanger sequencing; however, the sensitivity of this technology is limited in that it is unlikely to detect in individuals a variant present at a frequency of less than $20-30 \%$ of the quasispecies [24]. This limitation can lead to underestimating the burden of resistance in drug-naïve individuals, particularly for persons diagnosed long after becoming infected when transmitted resistant viruses may have become supplanted by more fit wildtype virus. Resistance 
can also be underestimated in ART-experienced individuals who may have low-expressing archived variants selected by prior treatment regimens [25]. The development of sensitive genotyping tools that allow for finer resolution of quasispecies subpopulations has uncovered hidden drug-resistant variants that are undetected by conventional sequencing. Some of the more common molecular methods used for resistance mutation detection include allele-specific or mutation-specific real-time PCR [26, 27], parallel allele-specific sequencing [28], ultra-deep (pyro) sequencing [29], and single-genome sequencing [30], each with inherent technical complexities and resource requirements.

In a study of newly diagnosed ART-naïve individuals from North America, who had either wildtype HIV infections or who had at least one resistance-associated mutation as determined by conventional genotyping, allele (mutation)-specific PCR testing found previously undetected low-frequency transmitted resistance mutations in both groups [31]. The detection of minority resistance mutations in $17 \%$ of the conventionally genotyped wildtype virus samples and the identification of additional mutations in $10 \%$ of those with evidence of other resistance mutations suggested that bulk genotyping missed at least $40 \%$ of transmitted mutations in this population. Furthermore, the finding that some individuals had evidence of HIV resistant variants of distinct genotypes implied that it was possible for infections to involve more than one variant with the potential to impact treatment outcomes. Sensitive genotyping for surveillance, however, may not offer substantially more information than conventional genotyping in geographic regions with lessextensive treatment histories and lower prevalences of transmitted resistance.

In a case-control study also by Johnson et al. [31], mutation-specific PCR testing identified that 7/95 (7\%) persons who experienced virological failure on first-line efavirenz-based ART had low-frequency drug resistance mutations at baseline; whereas, low-frequency resistance was found in only $2 / 221(0.9 \%)$ treatment successes ( $\mathrm{p}=$ 0.0038 ). A study by Goodman et al. [32], using allele-specific PCR at a mutation lower cut-off of $0.5 \%$, found that minority-level detection of $\mathrm{K} 103 \mathrm{~N}$, a non-nucleoside reverse transcriptase inhibitor (NNRTI) mutation, when present at $\geq 2,000$ copies/ml was associated with a significant $\sim 47$-fold higher risk of virological failure in firstline NNRTI-based ART [32]. This suggested that higher resistant variant loads within low-level populations were more strongly associated with treatment failure. Simen et al. [33] employed ultra-deep sequencing with a mutation detection lower limit of $1 \%$ to assess resistance in drugnaïve patients starting ART within the Flexible Initial Retrovirus Suppressive Therapies (FIRST) study of 3 initial regimens. Twice as many participants were identified to have resistance mutations with ultra-deep sequencing than was detected by standard sequencing, $28 \%$ versus $14 \%$, respectively $(\mathrm{p}<0.001)$. The presence of NNRTI resistance detected only by ultra-deep sequencing was significantly associated with virologic failure (HR 2.50; 95\% CI, 1.17-5.36). Taken together, these findings strongly support that, at least for NNRTI combination therapies with dual NRTIs, NNRTI-resistant variants may retain their impact even if present at a low frequency within the quasispecies.

Low-frequency mutations, however, do not universally impact ART. Lataillade et al. [34] reported that in persons virologically failing on ritonavir-boosted protease inhibitor (PI/r) regimens, ultra-deep sequencing identified major protease inhibitor mutations at low levels only sporadically, and those variants remained susceptible to the boosted PI. Moreover, Codoñer et al. [35] retrospectively assessed the value of sensitive testing on predicting the success of salvage therapy for HIV-infected persons with heavy treatment histories and who have experienced virologic failure with deep salvage therapy. Here, again the additional few PI resistance mutations identified by deep sequencing prior to salvage therapy were inconsistently predictive of PI susceptibility.

Finally, another potential use for sensitive genotyping was revealed in the deep sequencing of the en $v \mathrm{~V} 3$ region by Swenson et al. [36] from participants who received either the R5-specific entry inhibitor maraviroc or the NNRTI efavirenz in the MERIT trial. In this analysis, identification of low-level non-R5-tropic viruses at study entry were associated with poorer maraviroc treatment outcomes than those in the efavirenz arm. Limiting maraviroc to those with only R5-tropic virus would have resulted in maraviroc having a noninferior response to efavirenz. Therefore, because minority-level resistance class and design of antiretroviral regimen can impact treatment success, the benefit of sensitive genotyping in clinical management requires further exploration.

\section{Conclusion}

The advent of new sequencing and bioinformatics tools are beginning to benefit the development of improved methods for treating and preventing HIV infection. Despite the complicated genetic variability of HIV, 
sequencing and bioinformatics tools provide promise for identification of future viral targets of HIV prevention methods. Comprehensive studies of immunogenetics and viral sequences are beginning to understand the complicated interplay between virus and host, whereby specific alleles are associated with faster or slower disease progression. Increasingly sensitive ARV drug resistance testing methods have made it possible to detect minority drug resistance mutations which may impact the success of clinical patient management. In summary, data generated by studies of viral genetics and human immunogenetics provide valuable information to guide development of new strategies to improve HIV treatment and prevention.

\section{References}

> Ng OT, Eyzaguirre LM, Carr JK, Chew KK, Lin L, Chua A, Leo YS, Redd AD, Quinn TC, Laeyendecker $O$ : Identification of new CRF51_01B in Singapore using full genome analysis of three HIV type 1 isolates. AIDS Res Hum Retroviruses 2012;28:527-530.

2 Keele BF: Identifying and characterizing recently transmitted viruses. Curr Opin HIV AIDS 2010;5:327-334.

-3 Duncan CJ, Sattentau QJ: Viral determinants of HIV-1 macrophage tropism. Viruses 2011; 3:2255-2279.

-4 Ssemwanga D, Lyagoba F, Ndembi N, Mayanja BN, Larke N, Wang S, Baalwa J, Williamson C, Grosskurth H, Kaleebu P: Multiple HIV-1 infections with evidence of recombination in heterosexual partnerships in a low risk rural clinical cohort in Uganda. Virology 2011;411: 113-131.

5 Gnanakaran S, Bhattacharya T, Daniels M, Keele BF, Hraber PT, Lapedes AS, Shen T, Gaschen B, Krishnamoorthy M, Li H, Decker JM, Salazar-Gonzalez JF, Wang S, Jiang C, Gao F, Swanstrom R, Anderson JA, Ping LH, Cohen MS, Markowitz M, Goepfert PA, Saag MS, Eron JJ, Hicks CB, Blattner WA, Tomaras GD, Asmal M, Letvin NL, Gilbert PB, Decamp AC, Magaret CA, Schief WR, Ban YE, Zhang M, Soderberg KA, Sodroski JG, Haynes BF, Shaw GM, Hahn BH, Korber B: Recurrent signature patterns in HIV-1 b clade envelope glycoproteins associated with either early or chronic infections. PLoS Pathog 2011; 7:e1002209.

6 Asmal M, Hellmann I, Liu W, Keele BF, Perelson AS, Bhattacharya T, Gnanakaran S, Daniels M, Haynes BF, Korber BT, Hahn BH, Shaw GM, Letvin NL: A signature in HIV-1 envelope leader peptide associated with transition from acute to chronic infection impacts envelope processing and infectivity. PloS One 2011;6:e23673.

7 Buchbinder SP, Mehrotra DV, Duerr A, Fitzgerald DW, Mogg R, Li D, Gilbert PB, Lama JR, Marmor M, Del Rio C, McElrath MJ, Casimiro DR, Gottesdiener KM, Chodakewitz JA, Corey L, Robertson MN; Step Study Protocol T: Efficacy assessment of a cell-mediated immunity HIV-1 vaccine (the Step Study): a double-blind, randomised, placebo-controlled, test-of-concept trial. Lancet 2008;372:1881-1893.
Rolland M, Tovanabutra S, deCamp AC, Frahm N, Gilbert PB, Sanders-Buell E, Heath L, Magaret CA, Bose M, Bradfield A, O'Sullivan A, Crossler J, Jones T, Nau M, Wong K, Zhao H, Raugi DN, Sorensen S, Stoddard JN, Maust BS, Deng W, Hural J, Dubey S, Michael NL, Shiver J, Corey L, Li F, Self SG, Kim J, Buchbinder S, Casimiro DR, Robertson MN, Duerr A, McElrath MJ, McCutchan FE, Mullins JI: Genetic impact of vaccination on breakthrough HIV-1 sequences from the STEP trial. Nat Med 2011;17:366-371.

-9 Shea PR, Shianna KV, Carrington M, Goldstein DB: Host genetics of HIV acquisition and viral control. Annu Rev Med 2012, E-pub ahead of print.

10 Henn MR, Boutwell CL, Charlebois P, Lennon NJ, Power KA, Macalalad AR, Berlin AM, MalboeufCM, Ryan EM, Gnerre S, Zody MC, Erlich RL, Green LM, Berical A, Wang Y, Casali M, Streeck H, Bloom AK, Dudek T, Tully D, Newman R, Axten KL, Gladden AD, Battis L, Kemper M, Zeng Q, Shea TP, Gujja S, Zedlack C, Gasser O, Brander C, Hess C, Gunthard HF, Brumme ZL, Brumme CJ, Bazner S, Rychert J, Tinsley JP, Mayer KH, Rosenberg E, Pereyra F, Levin JZ, Young SK, Jessen H, Altfeld M, Birren BW, Walker BD, Allen TM: Whole genome deep sequencing of HIV-1 reveals the impact of early minor variants upon immune recognition during acute infection. PLoS Pathog 2012;8:e1002529.

11 Fellay J, Shianna KV, Telenti A, Goldstein DB: Host genetics and HIV-1: the final phase? PLoS Pathog 2010;6:e1001033.

12 International HIV Controllers Study, Pereyra F, Jia X, McLaren PJ, Telenti A, et al: The major genetic determinants of HIV-1 control affect HLA class I peptide presentation. Science 2010;330:1551-1557.

13 McLaren PJ, Ripke S, Pelak K, Weintrob AC, Patsopoulos NA, Jia X, Erlich RL, Lennon NJ, Kadie CM, Heckerman D, Gupta N, Haas DW, Deeks SG, Pereyra F, Walker BD, de Bakker PI; International HIV Controllers Study: Fine-mapping classical HLA variation associated with durable host control of HIV-1 infection in African Americans. Hum Mol Genet 2012;21:4334-4347.
14 Kløverpris HN, Harndahl M, Leslie AJ, Carlson JM, Ismail N, van der Stok M, Huang KH, Chen F, Riddell L, Steyn D, Goedhals D, van Vuuren C, Frater J, Walker BD, Carrington M, Ndung'u T, Buus S, Goulder P: HIV control through a single nucleotide on the $H L A-B$ locus. J Virol 2012;86:11493-11500.

15 Julg B, Moodley ES, Qi Y, Ramduth D, Reddy S, Mncube Z, Gao X, Goulder PJ, Detels R, Ndung'u T, Walker BD, Carrington M: Possession of HLA class II DRB1 ${ }^{\star} 1303$ associates with reduced viral loads in chronic HIV-1 clade C and B infection. J Infect Dis 2011;203: 803-809.

16 Ranasinghe S, Flanders M, Cutler S, Soghoian DZ, Ghebremichael M, Davis I, Lindqvist M, Pereyra F, Walker BD, Heckerman D, Streeck $\mathrm{H}$ : HIV-specific CD4 T cell responses to different viral proteins have discordant associations with viral load and clinical outcome. J Virol 2012;86:277-283.

17 Paris R, Bejrachandra S, Thongcharoen P, Nitayaphan S, Pitisuttithum P, Sambor A, Gurunathan S, Francis D, Ratto-Kim S, Karnasuta C, de Souza MS, Polonis VR, Brown AE, Kim JH, Stephens HA: HLA class II restriction of HIV-1 clade-specific neutralizing antibody responses in ethnic Thai recipients of the RV144 prime-boost vaccine combination of ALVAC-HIV and AIDSVAX ${ }^{\circ}$ B/E. Vaccine 2012;30:832-836.

18 Letvin NL, Rao SS, Montefiori DC, Seaman MS, Sun Y, Lim SY, Yeh WW, Asmal M, Gelman RS, Shen L, Whitney JB, Seoighe C, Lacerda M, Keating S, Norris PJ, Hudgens MG, Gilbert PB, Buzby AP, Mach LV, Zhang J, Balachandran H, Shaw GM, Schmidt SD, Todd JP, Dodson A, Mascola JR, Nabel GJ: Immune and genetic correlates of vaccine protection against mucosal infection by SIV in monkeys. Sci Transl Med 2011;3:81ra36.

19 Tang J, Cormier E, Gilmour J, Price MA, Prentice HA, Song W, Kamali A, Karita E, Lakhi S, Sanders EJ, Anzala O, Amornkul PN, Allen S, Hunter E, Kaslow RA; African HIV Research Network: Human leukocyte antigen variants $\mathrm{B}^{\star} 44$ and $\mathrm{B}^{\star} 57$ are consistently favorable during two distinct phases of primary HIV-1 infection in sub-Saharan Africans with several viral subtypes. J Virol 2011;85:88948902. 
20 Rajapaksa US, Li D, Peng YC, McMichael AJ, Dong T, Xu XN: HLA-B may be more protective against HIV-1 than HLA-A because it resists negative regulatory factor (Nef) mediated down-regulation. Proc Natl Acad Sci USA 2012;109:13353-13358.

-21 Kulkarni S, Savan R, Qi Y, Gao X, Yuki Y, Bass SE, Martin MP, Hunt P, Deeks SG, Telenti A, Pereyra F, Goldstein D, Wolinsky S, Walker $B$, Young HA, Carrington M: Differential microRNA regulation of $H L A-C$ expression and its association with HIV control. Nature 2011; 472:495-498.

22 Alter G, Heckerman D, Schneidewind A, Fadda L, Kadie CM, Carlson JM, Oniangue-Ndza C, Martin M, Li B, Khakoo SI, Carrington M, Allen TM, Altfeld M: HIV-1 adaptation to NK-cell-mediated immune pressure. Nature 2011;476:96-100.

23 US Department of Health and Human Services Guidelines for the Use of Antiretroviral Agents in HIV-1-Infected Adults and Adolescents. 2006. http://aidsinfo.nih.gov/guidelines.

24 Halvas EK, Aldrovandi GM, Balfe P, Beck IA, Boltz VF, Coffin JM, Frenkel LM, Hazelwood JD, Johnson VA, Kearney M, Kovacs A, Kuritzkes DR, Metzner KJ, Nissley DV, Nowicki M, Palmer S, Ziermann R, Zhao RY, Jennings CL, Bremer J, Brambilla D, Mellors JW: Blinded, multicenter comparison of methods to detect a drug-resistant mutant of human immunodeficiency virus type 1 at low frequency. J Clin Microbiol 2006;44:2612-2614.

25 Le T, Chiarella J, Simen BB, Hanczaruk B, Egholm M, Landry ML, Dieckhaus K, Rosen MI, Kozal MJ: Low-abundance HIV drug-resistant viral variants in treatment-experienced persons correlate with historical antiretroviral use. PLoS One 2009;4:e6079.
Palmer S, Boltz V, Martinson N, Maldarelli F, Gray G, McIntyre J, Mellors J, Morris L, Coffin J: Persistence of nevirapine-resistant HIV1 in women after single-dose nevirapine therapy for prevention of maternal-to-fetal HIV-1 transmission. Proc Natl Acad Sci USA 2006; 103:7094-7099.

27 Johnson JA, Li JF, Wei X, Lipscomb J, Bennett D, Brant A, Cong ME, Spira T, Shafer RW, Heneine W: Simple PCR assays improve the sensitivity of HIV-1 subtype B drug resistance testing and allow linking of resistance mutations. PLoS One 2007;2:e638.

28 Cai F, Chen H, Hicks CB, Bartlett JA, Zhu J, Gao F: Detection of minor drug-resistant populations by parallel allele-specific sequencing. Nat Methods 2007;4:123-125.

29 Margulies M, Egholm M, Altman WE, Attiya S, Bader JS, Bemben LA, Berka J, Braverman MS, Chen YJ, Chen Z, Dewell SB, Du L, Fierro JM, Gomes XV, Godwin BC, He W, Helgesen S, Ho CH, Irzyk GP, Jando SC, Alenquer ML, Jarvie TP, Jirage KB, Kim JB, Knight JR, Lanza JR, Leamon JH, Lefkowitz SM, Lei M, Li J, Lohman KL, Lu H, Makhijani VB, McDade KE, McKenna MP, Myers EW, Nickerson E, Nobile JR, Plant R, Puc BP, Ronan MT, Roth GT, Sarkis GJ, Simons JF, Simpson JW, Srinivasan M, Tartaro KR, Tomasz A, Vogt KA, Volkmer GA, Wang SH, Wang Y, Weiner MP, Yu P, Begley RF, Rothberg JM: Genome sequencing in microfabricated highdensity picolitre reactors. Nature 2005;437: 376-380.

30 Palmer S, Kearney M, Maldarelli F, Halvas EK, Bixby CJ, Bazmi H, Rock D, Falloon J, Davey RT Jr, Dewar RL, Metcalf JA, Hammer S, Mellors JW, Coffin JM: Multiple, linked human immunodeficiency virus type 1 drug resistance mutations in treatment-experienced patients are missed by standard genotype analysis. J Clin Microbiol 2005;43:406-413.

- 31 Johnson JA, Li JF, Wei X, Lipscomb J, Irlbeck D, Craig C, Smith A, Bennett DE, Monsour M, Sandstrom P, Lanier ER, Heneine W: Minority HIV-1 drug resistance mutations are present in antiretroviral treatment-naïve populations and associate with reduced treatment efficacy. PLoS Med 2008;5:e158.
32 Goodman DD, Zhou Y, Margot NA, McColl DJ, Zhong L, Borroto-Esoda K, Miller MD, Svarovskaia ES: Low level of the K103N HIV1 above a threshold is associated with virological failure in treatment-naive individuals undergoing efavirenz-containing therapy. AIDS 2011;25:325-333.

33 Simen BB, Simons JF, Hullsiek KH, Novak RM, Macarthur RD, Baxter JD, Huang C, Lubeski C, Turenchalk GS, Braverman MS, Desany B, Rothberg JM, Egholm M, Kozal MJ; Terry Beirn Community Programs for Clinical Research on AIDS: Low-abundance drugresistant viral variants in chronically HIV-infected, antiretroviral treatment-naive patients significantly impact treatment outcomes. J Infect Dis 2009;199:693-701.

34 Lataillade M, Chiarella J, Yang R, Degrosky M, Uy J, Seekins D, Simen B, St John E, Moreno E, Kozal M: Virologic failures on initial boosted-PI regimen infrequently possess lowlevel variants with major PI resistance mutations by ultra-deep sequencing. PLoS One 2012;7:e30118.

35 Codoner FM, Pou C, Thielen A, Garcia F, Delgado R, Dalmau D, Alvarez-Tejado M, Ruiz L, Clotet B, Paredes R: Added value of deep sequencing relative to population sequencing in heavily pre-treated HIV-1-infected subjects. PLoS One 2011;6:e19461.

36 Swenson LC, Mo T, Dong WW, Zhong X, Woods CK, Thielen A, Jensen MA, Knapp DJ, Chapman D, Portsmouth S, Lewis M, James I, Heera J, Valdez H, Harrigan PR: Deep V3 sequencing for HIV type 1 tropism in treatment-naive patients: a reanalysis of the merit trial of maraviroc. Clin Infect Dis 2011;53: 732-742. 